\title{
Anti-wrinkle and Skin turnover Improvement Effects of Niacinamide-dipeptide Convergence
}

\author{
Ga Yeon $\mathrm{Kim}^{1}$, Seung Je Lee ${ }^{1}$, Mi Ji Jeon ${ }^{1}$, Bo Min Kim ${ }^{1}$, Geun Tae Kim ${ }^{1}$, Sang Moon Kang ${ }^{2}$, Kee Young Lee ${ }^{2}$, Eun Jin Shin ${ }^{2}$, Sang Yong Kim ${ }^{3}$, \\ Young Min $\mathrm{Kim}^{1+}$ \\ ${ }^{1}$ Department of Biological Sciences and Biotechnology, Hannam University, Daejeon, Korea \\ ${ }^{2}$ A\&PEP Affiliated R\&D Center, Cheongju-si, Chuncheongbuk-do, Korea \\ ${ }^{3}$ Department of Food Science \& Bio Technology, Shinansan University, Ansan-si, Gyeonggi-do, Korea
}

\begin{abstract}
"Corresponding author: Yong Min Kim, Department of Biological Sciences and Biotechnology, Hannam University, 70 Hannamro, Daedeok-Gu, Daejeon 34430, Korea
\end{abstract}

Tel.: +82 426298760

Fax: +82 426298873

Email: kym@hnu.kr

Received December 7, 2017

Revised April 21, 2018

Accepted April 30, 2018

Published June 30, 2018

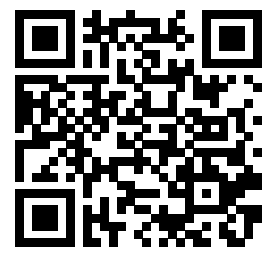

\begin{abstract}
Purpose: This study aimed to determine the anti-wrinkle and skin turnover improvement effects of niacinamide-dipeptide convergence (N-peptide). Methods: The following methods were employed to assess the anti-wrinkle and skin turnover improvement effects of N-peptide: 3-(4,5-Dimethylthiazol-2yl)-2,5-diphenyltetrazolium bromide (MTT) assay, wound healing assay, chicken chorioallantoic membrane (CAM) assay, reverse transcription polymerase chain reaction (RT-PCR), and three-dimensional (3D) cell culture. Results: The MTT assay revealed that the $\mathrm{N}$-peptide does not exert a cytotoxic effect in human keratinocytes (HaCaT). Moreover, the scratch wound healing and CAM assays showed that the $\mathrm{N}$-peptide induced migratory properties and angiogenesis, respectively, in $\mathrm{HaCaT}$ cells. The expression of matrix metalloproteinases $(M M P)-1,-2,-3$, and -9 was measured using RT-PCR to evaluate the anti-wrinkle effect of $\mathrm{N}$-peptides. The findings demonstrated that $\mathrm{N}$-peptides were responsible for reducing the expression of the aforementioned MMPs. In addition, using western blotting, N-peptides were identified to increase energy metabolism activity. Furthermore, 3D cell culture analysis indicated improvement in the skin turnover rate because of the $\mathrm{N}$-peptides. Conclusion: Taken together, these results suggest that N-peptides may be a source of cosmetic agents for the improvement of wrinkles and skin turnover.
\end{abstract}

Keywords: Niacin-dipeptide convergence, Functional cosmetic, Anti-wrinkle, Skin barrier, Skin turnover rate

\section{Introduction}

인체의 약 $16 \%$ 를 차지하는 피부는 각질 아래 표피, 진피, 피 하조직으로 구성되어 있으며, 외부 유해인자들로부터 인체를 보 호하는 중요한 역할을 한다(Yang et al., 2010). 그러나 나이가 들어감에 따라 각종 오염물질 및 스트레스에 의해 피부 세포들이 손상을 입게 되고, 세포 증식이 억제되어 피부의 탄력성과 윤택 성이 감소되고, 기미, 주근깨 등 피부 색소 침착 및 주름이 생기 게 된다(Yang et al., 2010; Lee et al., 2014a). 이와 같은 피 부 노화 현상(skin aging)은 피부 각질층의 구조적, 기능적 변화 로 인한 것으로, 그 요인에 따라 외인성 노화(extrinsic aging) 와 내인성 노화(intrinsic aging)로 구분할 수 있다(Lee et al., 2014a; Yoo et al., 2010). 외인성 노화는 자외선 및 스트레스 등과 같은 외부 요인에 의한 피부 노화를 말하며, 내인성 노화는 나이가 들어감에 따라 피부의 생리적 기능이 저하되어 자연스럽 게 나타나는 현상이다(Yoo et al., 2010).

피부의 진피 층은 피부의 물리, 화학적 성질을 결정하는 역할 을 하며, 진피의 대부분은 콜라겐(collagen)과 탄력섬유(elastic fiber)가 차지한다(Kim et al., 2000). 교원질 즉 콜라겐과 탄력 섬유는 피부의 기계적 견고성, 조직의 결합력 및 탄력성 등에 관 여한다(Jeon \& Kang, 2009; Kim et al., 2000). 그 중 콜라겐 은 진피의 $90 \%$ 이상을 차지하고 있으면서 외부로부터의 자극에 대해 피부를 보호하는 역할을 하는데, 이러한 콜라겐이 내부 또 는 외부로부터 자극을 받게 되면 구조 변화, 생합성량 감소 등을 
겪는다. 그로 인해 피부 진피 층에 존재하는 세포외 기질이 손상 되어 피부 주름이 만들어지게 된다(Jeon \& Kang, 2009).

콜라겐은 전구체(procollagen) 형태로 합성된 후 세포 밖 으로 배출되어 $\mathrm{pN}$ collagen, $\mathrm{pC}$ collagen 등의 중간 산물 을 거쳐 합성이 되며, 현재까지 19 종류의 콜라겐이 밝혀 져 있다(Scharffetter-Kochanek et al., 2000; Lee et al., 2014b). 콜라겐의 분해와 관련된 다양한 메커니즘 중 하나 는 전사인자인 activating protein-1 (AP-1)에 의한 것으로, $\mathrm{AP}-1$ 에 의해 유도되는 기질 금속 단백질 분해 효소(matrix metalloproteinases, MMPs)에 의해서 세포외 기질과 프로콜 라겐 및 콜라겐으로 분해된다(Scharffetter-Kochanek et al., 2000; Yoo et al., 2010). MMPs는 아연 이온을 필요로 하는 단 백질 분해 효소로 세포외 기질 단백질을 분해하는 효소이며 지 금까지 24 종류가 알려져 있다(Pyun et al., 2012; So et al., 2008). MMPs 중 MMP-1 (collagenase)은 콜라겐 타입 I, III 을 분해하고, MMP-3 (stromelysin-1)은 콜라겐 타입 IV을 분 해하며 MMP-9 (gelatinase B)는 콜라게나아제에 의해 분해된 산물을 더 작게 가수분해한다(Pyun et al., 2012).

최근 들어 피부 주름 개선에 효과가 있는 화장품에 대한 관심 이 높아지면서 기능성 화장품 소재를 탐색하기 위한 연구가 활 발히 이루어 지고 있다(Kim et al., 2009). 그 중 단백질 가수 분해물로부터 얻어진 펩타이드는 아미노산 서열이 가지는 배열 및 구조에 따라 생체 내 혹은 피부에서 생리활성을 가지게 되어 생물학적 제제로서의 산업적 응용 가능성이 높다(Jung et al., 2015; Kim et al., 2009; Kim et al., 2016). 또한 최근에는 재조합 과정을 통해 합성된 펩타이드 연구가 활발히 이루어 지고 있는 추세이다(Lupo \& Cole, 2007). 따라서 본 연구에서는 기 능성 화합물-펩타이드 융합체를 이용한 신규 기능성 화장품 소 재를 개발할 목적으로 항노화 기능성 물질-나이아신 펩타이드 융합체가 주름 개선 및 피부 에너지 대사에 미치는 영향을 확인 하고자 하였다.

\section{Methods}

\section{1. 실험재료}

1) 시약 및 기기

실험에 사용된 3-(4,5)dimethyl-2 thiazolyl)-2,5diphny-2H-tetra-zolium bromide (MTT)는 SigmaAldrich (USA)에서 구입하였으며, $94.5 \%$ 에탄올(ethanol), 클로로폼(chloroform), 포름알데히드(formaldehyde)는 SAMCHUN (Korea)의 제품을, 이소프로판올(isopropanol) 은 JUNSEI CHEMICAL (Japan)의 제품을 사용하였다. 시료 의 흡광도는 ELISA microplate reader (Model 680; Bio-Rad
Laboratories, Japan)를 사용하여 측정하였다.

2) 펩타이드 융합체 제조

본 실험에 사용된 나이아신 디펩타이드 융합체는 A\&PEP (Korea)에서 공급받아 사용하였다. N-peptide1 (molecular weight: $311.29 \mathrm{Da}$ )과 $\mathrm{N}$-peptide2 (molecular weight: $313.33 \mathrm{Da})$ 는 피부 미백 기능성 물질로 잘 알려진 나이아신아미 드에 2종의 dipeptide를 각각 결합시킨 신규 융합 펩타이드다.

\section{3) 세포주 배양}

본 실험에서 사용된 $\mathrm{HaCaT}$ (human keratinocyte cell line) 세포는 Dr. N. Fusenig (German Cancer Research Center, DKFZ, Germany)로부터 분양 받았으며, human fibroblast 세 포는 American Type Culture Collection (ATCC; Rockville, $\mathrm{USA}$ )에서 분양 받아 사용하였다. 세포는 $10 \% \mathrm{FBS}$ 와 $1 \%$ antibiotics가 포함된 Dulbecco's Modified Eagle Medium (DMEM; Hyclone ${ }^{\mathrm{TM}}$, USA) media를 사용하였으며, $5 \% \mathrm{CO}_{2}$, $37^{\circ} \mathrm{C}$ incubator에서 배양하였다. 매 $48 \mathrm{~h}$ 마다 trypsin-EDTA (Hyclone $\left.{ }^{\mathrm{TM}}\right)$ 를 이용하여 세포를 부유상태로 만든 다음 세포를 1 $\times 10^{6} \mathrm{cells} / \mathrm{mL}$ 로 분주하여 계대 배양하였다.

\section{2. 실험방법}

\section{1) MTT assay}

12 well plate에 $\mathrm{HaCaT}$ 세포를 $1 \times 10^{6}$ cells/well로 분주한 다음 $5 \% \mathrm{CO}_{2}, 37^{\circ} \mathrm{C}$ incubator에서 $24 \mathrm{~h}$ 동안 배양하였다. 그 후, 시료 $\mathrm{N}$-peptide1과 $\mathrm{N}$-peptide2를 농도별 $(100 \mu \mathrm{g} / \mathrm{mL}$, $500 \mu \mathrm{g} / \mathrm{mL}, 1 \mathrm{mg} / \mathrm{mL}$ )로 처리한 후 $24 \mathrm{~h}$ 동안 $\mathrm{CO}_{2}$ incubator 에서 배양하였다. $5 \mathrm{mg} / \mathrm{mL}$ solution을 각 well 당 $40 \mu \mathrm{L}$ 씩 최 종 농도가 $200 \mu \mathrm{g} / \mathrm{mL}$ 가 되도록 처리한 후 $30 \mathrm{~min}$ 동안 반응시 킨 다음 media를 제거하였다. 각 well 당 dimethyl sulfoxide (DMSO; SAMCHUN, Korea) $150 \mu \mathrm{L}$ 을 첨가한 후 96 well plates에 $100 \mu \mathrm{L}$ 씩 옮긴 후 ELISA microplate reader (680; Bio-Red laboratories, Japan)로 $595 \mathrm{~nm}$ 에서 흡광도를 측정 하였다. 모두 3 번 이상 측정하였으며, 이에 따른 평균값과 표준 오차는 Microsoft excel program을 이용하여 분석하였다.

\section{2) Wound healing assay}

$\mathrm{HaCaT}$ 세포를 6 well plate에 $2 \times 10^{6}$ cells/well로 분주 한 다음 세포가 confluent한 상태가 될 때까지 $5 \% \mathrm{CO}_{2}, 37^{\circ} \mathrm{C}$ incubator에서 배양하여 안정화를 유도하였다. 그런 다음 200 $\mu \mathrm{L}$ 의 tip (Neptune Scientific, USA)의 종단을 이용하여 세포 의 창상을 1 회 유도 하였으며 N-peptide 1 및 N-peptide 2 를 농 도별 $(100 \mu \mathrm{g} / \mathrm{mL}, 500 \mu \mathrm{g} / \mathrm{mL}, 1 \mathrm{mg} / \mathrm{mL})$ 로 처리 후, 시간대 별 $(0,12,24 \mathrm{~h})$ 로 세포의 이동 정도를 도립 현미경(Axiovert 
Table 1. Primer sequence for the amplification of target gene

\begin{tabular}{|c|c|c|c|}
\hline Gene & Primer sequence $\left(5^{\prime}-3^{\prime}\right)$ & Amplification size (bp) & Annealing temperature $\left({ }^{\circ} \mathrm{C}\right)$ \\
\hline \multirow{2}{*}{$M M P-1$} & For: ATGCTGAAACCCTGAAGGTG & \multirow{2}{*}{234} & \multirow{2}{*}{59.0} \\
\hline & Rev: CTGCTTGACCCTCAGAGACC & & \\
\hline \multirow{2}{*}{$M M P-2$} & For: ATGACAGCTGCACCACTGAG & \multirow{2}{*}{411} & \multirow{2}{*}{61.0} \\
\hline & Rev: TGATGTCATCCTGGGACAGA & & \\
\hline \multirow{2}{*}{$M M P-3$} & For: GCAGTTTGCTCAGCCTATCC & \multirow{2}{*}{214} & \multirow{2}{*}{58.5} \\
\hline & Rev: GAGTGTCGGAGTCCAGCTTC & & \\
\hline \multirow{2}{*}{ MMP-9 } & For: GAGACCGGTGAGCTGGATAG & \multirow{2}{*}{236} & \multirow{2}{*}{58.5} \\
\hline & Rev: TACACGCGAGTGAAGGTGAG & & \\
\hline \multirow{2}{*}{ GAPDH } & For: GGACTTCGAGCAAGAGATGG & \multirow{2}{*}{234} & \multirow{2}{*}{60.0} \\
\hline & Rev: AGCACTGTGTTGGCGTACAG & & \\
\hline
\end{tabular}

MMP-1, -2, -3, and -9, matrix metalloproteinase 1, 2, 3, 9.

100; Zeiss, Germany)을 이용하여 관찰하였다.

\section{3) Total RNA 추출 및 $\mathrm{cDNA}$ 합성}

$\mathrm{HaCaT}$ 세포를 각각 6 well plate에 $2 \times 10^{6}$ cells/well로 분주한 다음 $5 \% \mathrm{CO}_{2}, 37^{\circ} \mathrm{C}$ incubator에서 $24 \mathrm{~h}$ 동안 안정 화 시켰다. 그 후, 시료 $\mathrm{N}$-peptide 1 과 $\mathrm{N}$-peptide 2 의 최종 농도가 $500 \mu \mathrm{g} / \mathrm{mL}$ 가 되도록 처리하여 $24 \mathrm{~h}$ 동안 배양하였 다. 그 다음 RiboEX total RNA Isolation Solution (GeneAll Biotechnology, Korea) $500 \mu \mathrm{L}$ 를 각 well에 처리하고 상온 에서 $5 \mathrm{~min}$ 방치한 후 Scraper를 이용해 세포를 용해한 후 클 로로폼, 이소프로판올, $70 \%$ 에탄올을 각각 첨가하는 과정을 통하여 total RNA를 추출하였다. 그 후의 $\mathrm{cDNA}$ 합성 과정 은 DiaStar ${ }^{\mathrm{TM}}$ RT kit (SolGent, Korea)을 이용하여 진행하였 다. Total RNA $1 \mu \mathrm{L}$ 와 oligo (dT) 20 primer $9 \mu \mathrm{L}$ 를 혼합한 뒤 $65^{\circ} \mathrm{C}$ 에서 $5 \mathrm{~min}$ 동안 반응시킨 후에 $8 \mathrm{mM}$ dithiothreitol

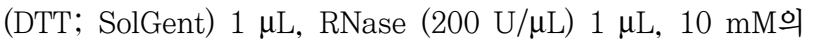
$\mathrm{dNTP}$ 가 포함된 $5 \mathrm{X}$ RT reaction buffer $4 \mu \mathrm{L}, \mathrm{DEPC}-\mathrm{DW}$ 를 첨가한 다음 $40{ }^{\circ} \mathrm{C}$ 에서 $1 \mathrm{~h}, 95^{\circ} \mathrm{C}$ 에서 $5 \mathrm{~min}$ 반응을 통하여 $\mathrm{cDNA}$ 를 합성하였다.

\section{4) 역전사 중합 효소 연쇄 반응(RT-PCR)}

PCR은 Solg ${ }^{\mathrm{TM}}$ 2X Taq PCR Smart mix 1 (SolGent)를 이 용하여 실시하였다. $\mathrm{PCR}$ 조건은 $95{ }^{\circ} \mathrm{C}$ 에서 $10 \mathrm{~min}$ 동안 예 비 가열 후, $95^{\circ} \mathrm{C}$ 에서 $30 \mathrm{~s}$ denaturation, 각 specific primer sequences에 맞는 온도에서 $30 \mathrm{~s}$ annealing, $72{ }^{\circ} \mathrm{C}$ 에서 30 $\mathrm{s}$ extension 과정을 35 회 반복하였으며 $72{ }^{\circ} \mathrm{C}$ 에서 $10 \mathrm{~min}$ 동 안 안정화 과정을 진행하였다. $M M P-1, M M P-2, M M P-3$, $M M P-9, G A P D H$ 의 specific primer sequences는 Table 1 과 같다.

\section{5) Western blot}

6 well plate에 $\mathrm{HaCaT}$ 세포를 $2 \times 10^{6}$ cells/well로 분주 하여 $24 \mathrm{~h}$ 동안 $5 \% \mathrm{CO}_{2}, 37^{\circ} \mathrm{C}$ incubator에서 배양한 다음 $\mathrm{N}-$ peptide1과 $\mathrm{N}-$ peptide 2 를 각각 최종농도가 $500 \mu \mathrm{g} / \mathrm{mL}$ 가 되도록 처리하여 $24 \mathrm{~h}$ 동안 배양하였다. 그 다음 RIPA lysis buffer [25 mM Tris-Cl (pH 7.4), 1\% NP40, 0.5\% sodium deoxycholate, $150 \mathrm{mM} \mathrm{NaCl}, 1 \mathrm{mM} \mathrm{PMSF}$ ]를 각 well에 150 $\mu \mathrm{L}$ 씩 첨가하여 단백질을 분리한 뒤 $14,000 \mathrm{rpm}, 4^{\circ} \mathrm{C}$ 에서 20 $\min$ 동안 원심분리하여 상등액을 취하였다. 분리한 단백질은 ELISA-reader를 이용하여 $595 \mathrm{~nm}$ 에서 흡광도 측정 한 후, 정 량한 다음 $8 \%, 12 \%$ acrylamide gel을 이용하여 전기영동을 실 시하였다. 그 다음 nitro cellulose membrane에 transfer하고 $2 \%$ bovine serum albumin (BSA; Bovogen, Australia)를 이 용하여 blocking 한 후, 1 차 항체를 $4^{\circ} \mathrm{C}$ 에서 $18 \mathrm{~h}$ 반응시키고 2 차 항체를 결합시킨 다음 실험 결과를 측정하였다.

\section{6) CAM assay}

수정란을 구입하여 $70 \%$ 에탄올로 소독한 후에 $37^{\circ} \mathrm{C}, 90 \%$ 습 도가 유지되는 배양기에 넣어 3 일 동안 배양 후 수정란의 air $\mathrm{sac}$ 쪽에 직경 약 $2 \mathrm{~cm}$ 크기의 원형 창을 만들고 air sac 아래 의 막은 핀셋으로 제거한 다음 Tegaderm (3M Healthcare, $\mathrm{USA}$ )을 이용해 원형 창을 막은 후, 동일한 조건에서 2 일간 더 배양하였다. 5 일 째 되는 날, N-peptide1과 N-peptide2 500 $\mu \mathrm{g} / \mathrm{mL}$ 을 떨어뜨린 disk를 혈관 위에 올려놓은 후 3 일 더 배 양한 후에 혈관 신생 정도를 현미경(Nikon SMZ 445; Nikon Instruments Inc., Japan)으로 관찰하였다.

\section{7) Organotypic coculture을 통한 human skin model 제작}

Organotypic 3D culture는 Hiro Nakagawa (Li et al., 2011)의 방법을 따랐다. SPL Insert ${ }^{\mathrm{TM}}$ Haging 6 well plate 

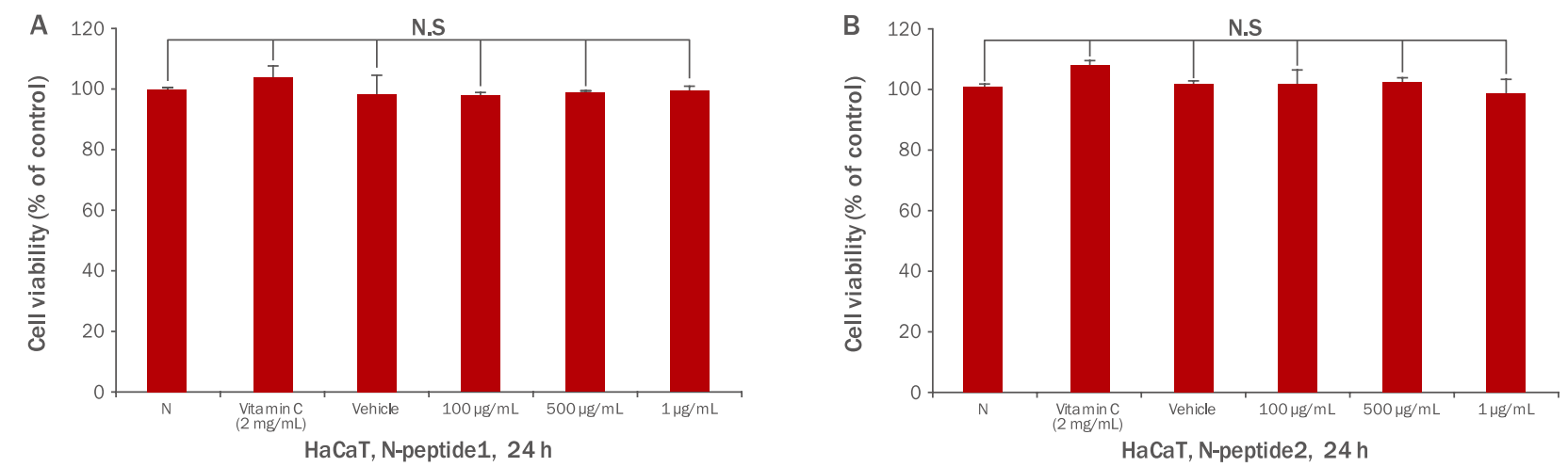

Figure 1. Cytotoxic effects of $\mathbf{N}$-peptides in HaCaT cells.

Cell viability was measured using MTT assay. Cells were treated with (A) N-peptide1 and (B) N-peptide2 for 24 h. Each experiment was performed in triplicates. Statistical analysis was performed using a $t$-test. N.S., not significant; N, negative control; Vitamin C, positive control; Vehicle, distilled water; N-peptide, niacinamide-dipeptide convergence; MTT, 3-(4,5-Dimethylthiazol-2-yl)-2,5diphenyltetrazolium bromide.

(SPL Life Sciences, Korea)에 Purecol ${ }^{\circledR}$ Bovine Collagen type I (Advanced BioMatrix, USA)을 $0.8 \mu \mathrm{m}$ pore size 를 갖는 inset 내부에 $1 \mathrm{~mL}$ 씩 분주하여 acellular layer를 만 든다. 겔이 굳은 뒤 배양한 human fibroblast $\left(2 \times 10^{7}\right.$ cells/ well)를 Matrigel ${ }^{\circledR}$ Basement Membrane Matrix (Corning ${ }^{\circledR}$, $\mathrm{USA}$ )와 함께 섞은 후, acellular layer 층 위에 $3 \mathrm{~mL}$ 을 분주 하여 cellular layer 층을 형성한 다음 $37^{\circ} \mathrm{C}, 5 \% \mathrm{CO}_{2}$ 조건의 incubator에서 5 일간 배양하였다. Human fibroblast를 배양 한 cellular layer 위에 DMEM media와 Ham's F12 media (HycloneTM)를 3:1로 섞은 배지를 넣어 gel matrix를 안정화 시킨 다음, $\mathrm{HaCaT}$ 세포 $\left(2 \times 10^{7}\right.$ cells $\left./ \mathrm{mL}\right)$ 를 basement cell layer에 $50 \mu \mathrm{L}$ 씩 분주하고, $37^{\circ} \mathrm{C}, 5 \% \mathrm{CO}_{2}$ 에서 $2 \mathrm{~h}$ 동안 안정 화 과정을 거쳐 2 주간 배양하였다. 그 다음 $\mathrm{HaCaT}$ 세포의 각 질 분화 유도 후, $\mathrm{N}$-peptide1과 $\mathrm{N}$-peptide2는 $500 \mu \mathrm{g} / \mathrm{mL}$, vitamin $\mathrm{C}$ 는 $10 \mu \mathrm{g} / \mathrm{mL}$ 이 되도록 7일 동안 배양하였다.

\section{8) Histology}

Organotypic co-culture한 샘플을 phosphate buffered saline (PBS; Hyclone $\mathrm{e}^{\mathrm{TM}}$ )로 2-3회 washing 후 $10 \%$ phosphate-buffered formaldehyde (SAMCHUN, Korea) 에 넣고 $1 \mathrm{~h}$ 동안 고정하였다. 탈수과정을 거친 후 paraffin 에 embedding하여 $5 \mu \mathrm{m}$ 크기로 section을 나누었다. 조직은 hematoxylin과 eosin으로 염색하여 피부세포의 각질 탈락주기 를 확인하였다.

\section{3. 통계 처리}

통계 프로그램인 SPSS 22.0을 사용하였고 실험 설계에 대 한 분산 분석은 일원배치 분산분석(one-way analysis of variance, one-way ANOVA)과 독립표본 $t$-test (independent sample $t$-test)를 실시하여 검정하였다. 각 자료는 3 번 이상의 반복된 실험을 통하여 얻어진 결과로 검정하였고 $p<0.05$ 인 경우 통계적으로 유의한 것으로 판정하였다.

\section{Results and Discussion}

\section{1. 나이아신 펩타이드 융합체의 세포 독성 검사}

피부 표피층의 $90 \%$ 이상을 구성하는 피부 각질형성세포 $(\mathrm{HaCaT})$ 는 피부 미백, 피부 재생 등과 관련된 많은 실험에서 널 리 사용되고 있는 세포주이다(Choung et al., 2013). 본 연구에 서는 나이아신 펩타이드 융합체 N-peptide1과 N-peptide2가 화장품 원료로써 피부를 구성하는 피부 세포에 대한 독성 여부 를 확인하기 위해 MTT assay를 실시하였다. MTT 분석은 세포 생존율을 측정하는 대표적인 실험방법 중 하나로 살아있는 세포 수에 비례해서 흡광도를 나타낸다(Jeon et al., 2011). HaCaT 세포에 나이아신 펩타이드 융합체 N-peptide1과 N-peptide2 를 각각 $24 \mathrm{~h}$ 동안 처리 후에 세포 생존율을 측정한 결과, Figure 1에 나타난 바와 같이 HaCaT 세포에서 N-peptide1과 $\mathrm{N}$-peptide2 농도별 $(100 \mu \mathrm{g} / \mathrm{mL}, 500 \mu \mathrm{g} / \mathrm{mL}, 1 \mathrm{mg} / \mathrm{mL})$ 처 리에 의한 세포 생존율이 $90 \%$ 이상으로 나타나 세포 독성이 나 타나지 않음을 확인하였다.

\section{2. 나이아신 펩타이드 융합체의 피부 재생 효과}

$\mathrm{HaCaT}$ 세포는 화학적 및 물리적 자극에 의해 손상을 받게 되 면 다양한 케모카인(chemokine)과 사이토카인(cytokine)을 분 비함과 동시에 피부 손상 부위로 이동해 세포의 증식을 유도한다 (Choung et al., 2013). 이러한 HaCaT의 증식 및 이주 활성은 콜라겐과 같은 피부 구성 단백질의 합성을 촉진하여 피부 재생과 
A

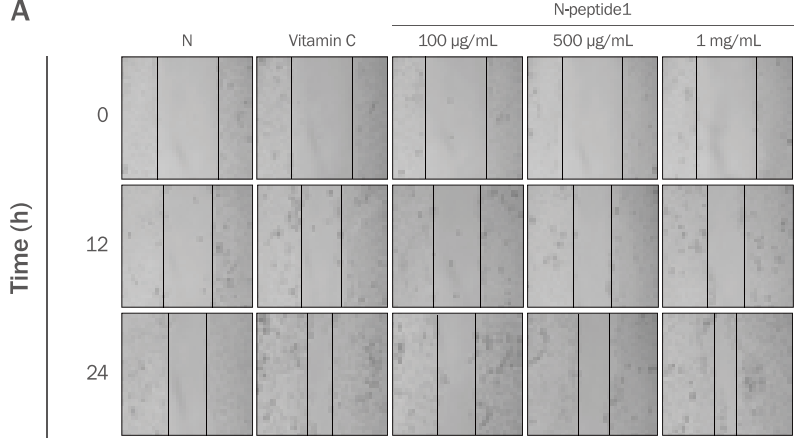

B

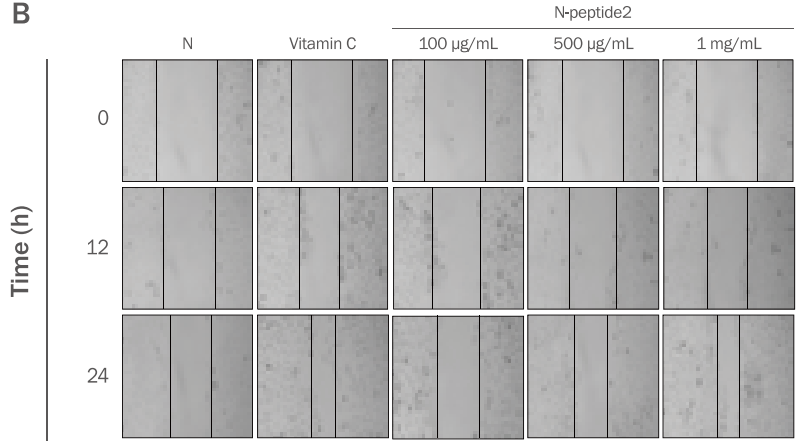

Figure 2. Skin regeneration effect of $\mathbf{N}$-peptides in $\mathrm{HaCaT}$ cells.

The wound healing assay was determined the migration of HaCaT cells. Wound was scratched at $100 \%$ confluence, and cells were treated with the indicated concentrations of (A) N-peptide1 and (B) N-peptide2 for $24 \mathrm{~h}$. Images were obtained at 0, 12, and 24 h. N, negative control; Vitamin C, positive control; N-peptide, niacinamide-dipeptide convergence.

상처 치유 등의 항노화를 유도한다(Choung et al., 2013). 따라 서 피부 세포의 성장 및 이동을 시험하는 wound healing assay 를 통해 나이아신 펩타이드 융합체의 세포 재생 유도 효과를 검 증하고자 하였다. Figure $2 \mathrm{~A}, 2 \mathrm{~B}$ 와 같이 $\mathrm{HaCaT}$ 세포에 나이아 신 펩타이드 융합체 $\mathrm{N}-$ peptide1과 $\mathrm{N}-$ peptide2를 $100 \mu \mathrm{g} / \mathrm{mL}$, $500 \mu \mathrm{g} / \mathrm{mL}, 1 \mathrm{mg} / \mathrm{mL}$ 의 농도로 처리했을 때, 시간 의존적으로 아무것도 처리하지 않은 무처리군에 비해 세포 성장 및 세포 이 동이 감소함을 확인하였다. N-peptide1의 경우, 농도별로 $55 \%$, $50 \%, 32 \%$ 로 wound area가 감소하였으며, N-peptide2의 경 우에는 $55 \%, 49 \%, 34 \%$ 로 감소하였다. 이러한 결과를 바탕으로 $\mathrm{N}$-peptide1과 $\mathrm{N}$-peptide2 두 시료 모두 $1 \mathrm{mg} / \mathrm{mL}$ 의 농도에 서 세포가 이동한 면적이 양성 대조군 vitamin $\mathrm{C}$ 와 동등하게 감 소되었음을 확인하였다. 따라서 본 실험을 통하여 나이아신 펩타 이드 융합체의 세포 재생 유도 효과를 확인할 수 있었다.

\section{3. 나이아신 펩타이드 융합체의 주름 관련 유전자 발현 억제 효과}

피부 세포의 결합 조직을 구성하는 성분 중 하나인 콜라겐은 피부 진피층에 존재하며 피부를 지지하는 역할을 한다. 이러한 콜라겐의 감소는 피부 노화를 이끄는 중요한 요인이 될 수 있 다. 콜라겐은 일반적으로 전사인자 $\mathrm{AP}-1$ 에 의해 유도되는 기 질 금속 단백질 분해 효소 $(\mathrm{MMPs})$ 에 의해서 분해된다(Yoo et al., 2010). MMPs는 피부 세포를 비롯한 많은 세포들로부터 분비되어 세포외 기질과 기저막(basement membrane, BM) 을 구성하는 대부분의 단백질 성분을 분해하며 주름과 피부 처 짐의 원인이 되는 것으로 알려져 있으며, domain에 의해 28 개 (MMP-1-MMP-28)로 나누어진다(Lee \& Lee, 2013; Yoo et al., 2010). MMP family 중 MMP-1은 콜라겐 타입 I을 분해시키는 대표적인 분해 효소로 알려져 있고, $\mathrm{MMP}-2$ 는 제 4 와 제 5 형 교원질 및 탄력소를 분해하고 $\mathrm{MMP}-3$ 의 경우, 라 미닌(laminin), 파이브로넥틴(fibronectin), 프로테오글리칸 (proteoglycan) 등 기질 단백질을 분해한다고 알려져 있다 (Kim et al., 2011; Lee \& Lee, 2013). 또한 gelatinase로 알 려진 MMP-9 역시 콜라겐을 분해한다(Hardie et al., 2012). 따라서 본 연구에서는 나이아신 펩타이드 융합체 $\mathrm{N}$-peptide1 과 $\mathrm{N}$-peptide 2 각각 $500 \mathrm{mg} / \mathrm{mL}$ 의 농도로 $\mathrm{HaCaT}$ 세포에 처리했을 때의 피부 노화 관련 유전자의 발현 정도를 알아보고 자 하였다. 그 결과, $\mathrm{N}$-peptide1과 $\mathrm{N}$-peptide 2 를 처리했을 때 $M M P-1,-2,-3,-9$ 의 발현이 아무것도 처리하지 않은 negative control 군에 비해 감소되는 것을 확인하였으며, 특 히 $M M P-3$ 의 경우 양성 대조군 vitamin $\mathrm{C}$ 와 유사하게 감소되 는 것을 확인하였다(Figure 3). 이를 통해, 나이아신 펩타이드 융합체가 주름 및 노화 방지에 효과가 있음을 알 수 있다.

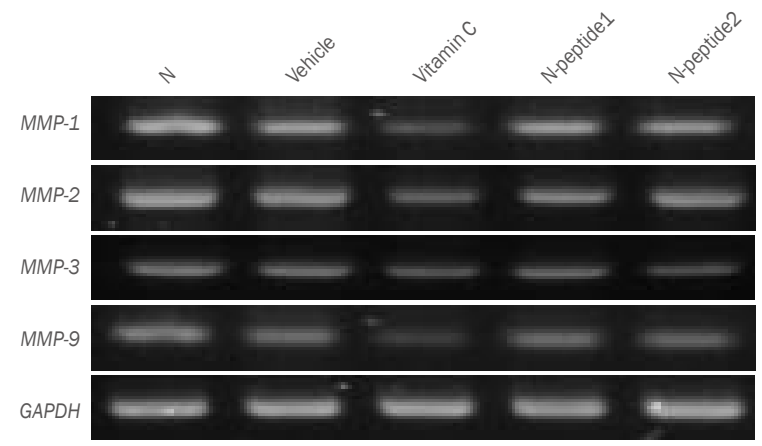

Figure 3. Regulation of MMP-1, -2,-3, and -9 mRNA expression levels in HaCaT cells by $\mathbf{N}$-peptides.

Cells were treated with vehicle, vitamin C ( $2 \mu \mathrm{g} / \mathrm{mL})$, N-peptide1 and N-peptide2 $(500 \mu \mathrm{g} / \mathrm{mL})$ for $24 \mathrm{~h}$. The expression level of $M M P-1,-2,-3$, and -9 was analyzed using RT-PCR. The GADPH was used as a loading control. $\mathrm{N}$, negative control; Vehicle, distilled water; Vitamin C, positive control; $\mathrm{N}$-peptide, niacinamide-dipeptide convergence; $M M P-1,-2$, -3 , and -9 , matrix metalloproteinase 1, 2, 3, and 9; RT-PCR, reverse transcription polymerase chain reaction; $G A P D H$, glyceraldehyde 3-phosphate dehydrogenase. 
A

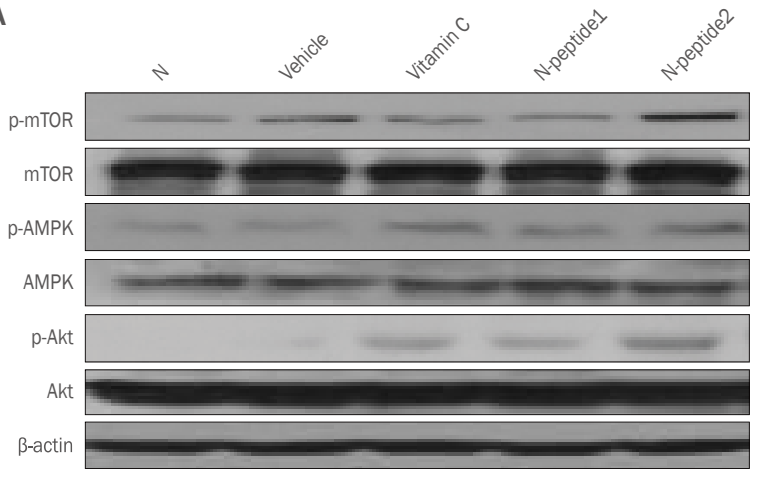

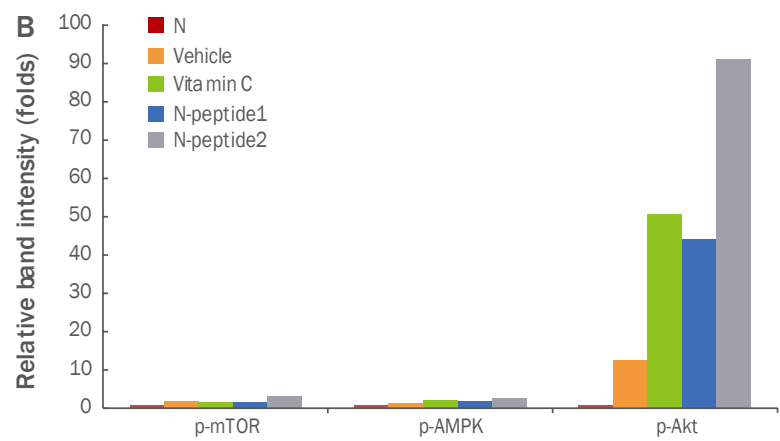

Figure 4. Regulation of energy metabolism-related protein expression levels in HaCaT cells by N-peptides.

Cells were treated with vehicle, vitamin C $(2 \mu \mathrm{g} / \mathrm{mL})$, N-peptide1 and N-peptide2 $(500 \mu \mathrm{g} / \mathrm{mL})$ for $24 \mathrm{~h}$. (A) The expression of mTOR, AMPK, and Akt was analyzed by western blotting. (B) Relative band intensity of energy metabolism-related proteins. The $\beta$-actin was used as a loading control. N, negative control; Vehicle, distilled water; Vitamin C, positive control; N-peptide, niacinamide-dipeptide convergence; p-mTOR, phosphorylated mammalian target of rapamycin; p-AMPK, phosphorylated AMPactivated protein kinase; p-Akt, phosphorylated protein kinase B.

\section{4. 나이아신 펩타이드 융합체가 피부 세포의 에너지 대사 관련 단 백질 발현에 미치는 영향}

나이아신 펩타이드 융합체 처리 시, 에너지 대사 관련 단백질 에 영향을 미치는 정도를 알아보고자 western blotting을 실시 하였다. AMP-activated protein kinase (AMPK)는 생체 내의 에너지 인식 및 항상성 조절, 당과 지방의 대사에 있어서 다른 여 러 대사 관련 효소들을 직접 인산화시켜 세포 내 에너지 균형 및 영양분 대사 조절에 중요한 역할을 하며, mammalian target of rapamycin (mTOR)는 세포 내 ATP 수준을 직접적으로 감지하 여 에너지 수준과 성장 요소를 제어한다(Son et al., 2005). 또 한 serine/threonine kinase인 Akt는 세포 밖 성장 인자에 의 한 신호를 세포 안으로 전달하며, 세포의 증식과 생존, 사멸, 당 대사를 조절한다(Yoon et al., 2007). 따라서 본 연구에서는 나 이아신 펩타이드 융합체가 피부 세포의 에너지 대사 관련 단백질 발현에 미치는 영향을 알아보기 위하여 western blotting을 실 시하였다. 그 결과, Figure $4 \mathrm{~A}, 4 \mathrm{~B}$ 와 같이 나이아신 펩타이드 융합체 N-peptide1과 N-peptide2를 HaCaT 세포에 $500 \mu \mathrm{g} /$ $\mathrm{mL}$ 의 농도로 처리했을 때, 에너지 대사 관련 단백질 $\mathrm{p}-\mathrm{mTOR}$, $\mathrm{p}-\mathrm{AMPK}, \mathrm{p}-\mathrm{Akt}$ 의 발현이 증가하는 것을 확인하였으며, $\mathrm{N}$-peptide1, 2 모두 양성 대조군 vitamin C에 비해 에너지 대 사 관련 단백질의 발현이 증가되는 것을 확인하였다. 이를 통해 나이아신 펩타이드 융합체 처리 시, 활발한 에너지 대사가 이루 어지며 이는 피부 재생과 항노화에 효과가 있는 것으로 여겨진 다.

\section{5. 나이아신 펩타이드 융합체의 혈관 신생 작용을 통한 피부 재생} 효과

혈관 신생은 상처 치유뿐만 아니라 암화 과정, 초기 발생 과
정 등 정상적인 상태에서도 중요한 역할을 담당하며, 피부에 있 어 영양 공급을 담당한다고 알려져 있다(Song \& Kim, 2009). 또한 내인성 노화의 경우, 혈관의 감소가 영양 공급 감소를 유 발하여 피부 노화의 원인이 된다는 연구 결과가 있다(Yoon et al., 2007). 따라서 나이아신 펩타이드 융합체 $\mathrm{N}$-peptide1 과 N-peptide2 $500 \mu \mathrm{g} / \mathrm{mL}$ 처리에 의한 혈관 신생 촉진 효과 를 확인하기 위해 ex vivo CAM assay를 실시한 결과, 혈관 신 생 작용이 활발한 것을 확인하였으며 양성 대조군으로 사용한 vitamin $\mathrm{C}$ 와 비례하여 혈관 신생을 촉진하는 것을 확인하였다 (Figure 5). 이를 통해 나이아신 펩타이드 융합체 N-peptide1 과 N-peptide2로 인한 피부 재생 효과 및 항노화 효과가 있는 것으로 여겨진다.

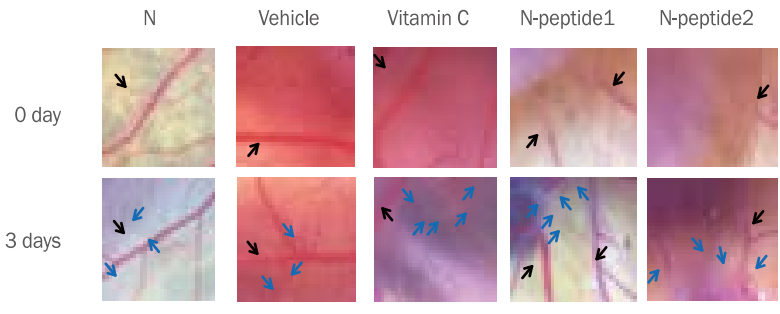

Figure 5. Effect of $\mathbf{N}$-peptides on angiogenesis.

5-day chick embryos were treated with vehicle, vitamin $\mathrm{C}$, $\mathrm{N}$-peptide1 and N-peptide2 $(500 \mu \mathrm{g} / \mathrm{mL})$ for $72 \mathrm{~h}$. Arrows indicate angiogenic vessels. $\mathrm{N}$, negative control; Vehicle, distilled water; Vitamin $\mathrm{C}$, positive control; N-peptide, niacinamide-dipeptide convergence; CAM, chicken choriallantoic membrane. 


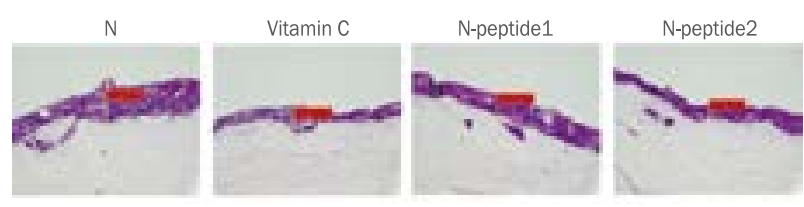

Figure 6. Improvement effect of $\mathbf{N}$-peptides on skin turnover. $\mathrm{N}$-peptide 1 and $\mathrm{N}$-peptide 2 regulated hyperkeratosis in organotypic culture of HaCaT cells. 3D organotypic skin co-cultures were established. The organotypic model was maintained for 14 days and treated for 7 days. Representative $\mathrm{H} \& \mathrm{E}$ stained sections were photographed using a Leica DM750 microscope at $10 x$ magnification. $\mathrm{N}$, negative control; Vitamin C, positive control; N-peptide, niacinamide-dipeptide convergence; $\mathrm{H} \& \mathrm{E}$, hematoxylin and eosin.

\section{3D cell culture}

최근 각질형성세포의 3 차원적인 배양을 통하여 여러가지 연구 가 진행되고 있는데, 이러한 3 차원 배양은 기존에 수행하던 단층 배양의 단점을 극복해 피부의 특징인 각질화를 형성하여 표피의 분화 연구, 피부 독성 검사 등 많은 피부 연구에 이용되고 있다 (Kim et al., 2000; Ravi et al., 2015; Yoon et al., 2007). 인 체 표피 중 $90 \%$ 이상을 차지하는 각질형성세포는 대략 28 일을 주기로 진피층에서 표피층으로 밀려나가 각질층으로부터 탈락 되며, 이러한 세포의 교체를 턴오버(tern-over)라고 한다(Kim, 2007; Ko et al., 2009). 피부의 턴오버 주기는 노화가 진행될 수록 각질형성세포의 기능이 저하되어 더 길어지는데, 이로 인 해 두꺼워진 각질층에 의해 피부가 거칠어지고 주름이 늘어나게 된다(Min \& Bae, 2013). 따라서 N-peptide1 및 N-peptide2 $500 \mu \mathrm{g} / \mathrm{mL}$ 처리에 의한 피부 턴오버 주기 개선 효과를 확인 하기 위해 $3 \mathrm{D}$ cell culture를 실시한 결과, 피부의 각질층이 양 성 대조군인 vitamic $\mathrm{C}$ 의 경우 $362.00 \mathrm{px}$, 나이아신 펩타이드 융합체 N-peptide1의 경우 $320.00 \mathrm{px}, \mathrm{N}$-peptide 2 의 경우 $198.00 \mathrm{px}$ 로 두 시료 모두 양성 대조군 vitamin C와 유사하거 나 더 감소함을 확인하였다(Figure 6). 이를 통하여 나이아신 펩 타이드 융합체가 피부 턴오버 주기 개선 효과를 가지고 있음을 알 수 있다.

\section{Conclusion}

MTT assay를 통하여 나이아신 펩타이드 융합체의 세포 독성 검사를 실시한 결과, $\mathrm{N}$-peptide1과 $\mathrm{N}$-peptide2 처리에 따른 세포 독성은 나타나지 않았다. 나이아신 펩타이드 융합체의 피 부 재생 효능을 확인하기 위하여 wound healing assay와 CAM assay를 실시한 결과, $\mathrm{N}$-peptide1과 N-peptide2이 양성 대조
군 vitamin $\mathrm{C}$ 와 유사하게 $\mathrm{HaCaT}$ 세포의 이동을 유도하는 것이 관찰되었으며, $\mathrm{CAM}$ model에서 역시 혈관 신생 작용이 활발하 게 이루어짐을 확인하였다.

노화의 대표적인 원인인 콜라겐 감소에 관여하는 MMPs 발현 측정에서는 $\mathrm{N}$-peptide1과 $\mathrm{N}$-peptide2 처리에 의해 $M M P-1$, $-2,-3,-9$ 의 발현이 감소하였으며, 이를 통해 N-peptide1 및 $\mathrm{N}$-peptide2가 주름 유발 관련 유전자의 발현을 억제시키는 것 을 확인하였다.

또한 피부 세포의 에너지 대사에 나이아신 펩타이드 융합체 가 미치는 영향을 확인하기 위하여 western blot을 실시하였 을 때, 에너지 대사에 관여하는 단백질들의 발현이 양성 대조군 vitamin C와 유사하거나 보다 증가함을 확인하였다.

마지막으로 나이아신 펩타이드 융합체의 피부 주름 개선 효 능 외에 전반적인 피부 턴오버 개선 효과를 확인하기 위해 $3 \mathrm{D}$ cell culture 후, hematoxylin \& eosin (H \& E) 염색 방법을 이용해 세포층 단면을 현미경으로 관찰한 결과, $\mathrm{N}$-peptide1과 $\mathrm{N}$-peptide2 처리군에서 피부 재생 유도 효과 및 턴오버 개선 효 과가 양성 대조군 vitamin $\mathrm{C}$ 와 유사하거나 더 높게 확인되었다.

결론적으로 피부 세포에 유해하지 않은 나이아신 펩타이드 융 합체는 단순 주름 개선 효능만이 아닌 피부의 턴오버 주기 개선 을 통한 피부의 과각질화 예방 효능 또한 있는 것으로 보아 주름 개선 및 피부 개선을 위한 기능성 화장품소재로서 이용될 수 있 을 것으로 사료된다.

\section{Acknowledgements}

본 연구는 2016년도 중기청 융복합사업(과제번호: S2356755) 에 의해 수행되었음.

\section{References}

Choung MG, Hwang YS, Kim GP, Ahn GK, Shim HS, Hong SB, Choi JH, Yu CY, Chung IM, Kim SH, et al. Antimelanogenic effect and whitening of antocyanin Rich Fraction from seeds of Liriope platyphylla. Korean Journal of Medicinal Crop Science, 21: 361-371, 2013.

Hardie DG, Ross FA, Hawley SA. AMPK: a nutrient and energy sensor that maintains energy homeostasis. Nature Reviews. Molecular Cell Biology, 13: 251-262, 2012.

Jeon MH, Park MR, Park YS, Hwang HJ, Kim SG, Lee SH, Kim M. Effect of pine (Pinus densiflora) needle extracts on antioxidant activity and proliferation of osteoclastic RAW 264.7 cells. Journal of the Korean Society of Food 
Science and Nutrition, 40: 525-530, 2011.

Jeon YS, Kang SM. Influence of collagen intake upon facial-skin wrinkles. Asian Journal of Beauty and Cosmetology, 7: 79-93, 2009.

Jung HS, Song MY, Kim HS, Seo HH, Lee JH, Lee KR, Hong I, Moh SH. Development of anti-wrinkle materials using galloyl-peptide derivatives. Journal of Korea AcademiaIndustrial Cooperation Society, 16: 5452-5457, 2015.

Kim DY, Hwang DI, Yoon MS, Choi IH, Lee HM. Effect of hydrosol extracted from Chrysanthemum boreale Makino flower on proliferation and migration in human skin keratinocyte. Journal of the Society of Cosmetic Scientists of Korea, 42: 95-101, 2016.

Kim EA. Phytochemicals and beauty food. Food Science and Industry, 40: 3-9, 2007.

Kim ID, Kwon RH, Heo YY, Jung HJ, Kang HY, Ha BJ. Supercritical extraction of oriental herb: Anti-aging and anti-wrinkle effects. Korean Society for Biotechnology and Bioengineering Journal, 23: 529-534, 2008.

Kim JK, Lee JH, Yang MS, Seo DB, Lee SJ. Beneficial effect of collagen peptide supplement on anti-aging against photodamage. Korean Journal of Food Science and Technology, 41: 441-445, 2009.

Kim SC, Hong NP, Choo JH, Park SH, Hong SC, Cha Cl. The tree-dimensional co-culture of cholesteatomatous keratinocyte and fibroblast. Korean Journal of Otorhinolaryngology Head and Neck Surgery, 43: 12731278, 2000.

Kim YC, Park EY, Kim SN, Yoo YG, Park MS, Lee GY, Lee SJ, Chan BS. Inhibitory effects of nude pack containing black tea water extract on skin wrinkle formation in hairless mice. Applied Microscopy, 41: 129-137, 2011.

Ko JY, Choi KH, Kim YC. Effect of Scirpi rhizoma ethanol extract on skin whitening in an animal model of brown guinea pigs. Environmental Health and Toxicology, 24: 219-229, 2009.

Lee BG, Kim JH, Ham SG, Lee CE. Study on biological activities of extracts for cosmeceutical development from Lagerstroemia indica L. branch. Korean Journal of Plant Reources, 27: 29-34, 2014b.

Lee KO, Kim SN, Kim YC. Anti-wrinkle effects of water extracts of teas in hairless mouse. Toxicological Research, 30: 283-289, $2014 a$.

Lee SY, Lee JY. Inhibitory efficacy of Smilax china L. on pro- collagen type-1 activity and MMP-1 gene expression in fibroblasts (CCD-986sk). Journal of Life Science, 23: 1239-1245, 2013.

Li L, Fukunaga-Kalabis M, Herlyn M. The three-dimensional human skin reconstruct model: a tool to study normal skin and melanoma progression. Journal of Visualized Experiments, 54: 2937, 2011.

Lupo MP, Cole AL. Cosmeceutical peptides. Dermatologic Therapy, 20: 343-349, 2007.

Min JA, Bae HS. The effect of Opuntia humifusa and microneedle therapy system on the women's facial skin. Asian Journal of Beauty and Cosmetology, 11: 149-157, 2013.

Pyun HB, Kim M, Park J, Sakai Y, Numata N, Shin JY, Shin HJ, Kim DU, Hwang JK. Effects of collagen tripeptide supplement on photoaging and epidermal skin barrier in UVB-exposed hairless mice. Preventive Nutrition and Food Science, 17: 245-253, 2012.

Ravi M, Paramesh V, Kaviya SR, Anuradha E, Solomon FD. 3D cell culture systems: advantages and applications. Journal of Cellular Physiology, 230: 16-26, 2015.

Scharffetter-Kochanek K, Brenneisen P, Wenk J, Herrmann G, Ma W, Kuhr L, Meewes C, Wlaschek M. Photoaging of the skin from phenotype to mechanisms. Experimental Gerontology, 35: 307-316, 2000.

So SH, Lee SK, Hwang El, Koo BS, Han GH, Chung JH, Lee MJ, Kim NM. Mechanisms of Korean red ginseng and herb extracts (KTNG0345) for anti-wrinkle activity. Journal of Ginseng Research, 32: 39-47, 2008.

Son UD, Hwang JS, Chang IS. Approach of antiaging care in cosmetics. Journal of the Society of Cosmetics Scientists of Korea, 31: 213-218, 2005.

Song JS, Kim YA. A study on the future market prospect of domestic functional cosmetics industry: focused on the cosmeceutical products. Journal of the Korean Society of Design Culture, 15: 258-271, 2009.

Yang WS, Kim YM, Kim EH, Seu YB, Yang YJ, Kim HW, Kang SC. Anti-wrinkle effect of cosmetics containing Duchesnea indica extract. Journal of the Society of Cosmetic Scientists of Korea, 36: 281-288, 2010.

Yoon HJ, Shin JW, Kim YK, Kim JE, Cho KH. The effect of vitamin $\mathrm{C}$ and $\mathrm{E}$ on the expression of the cutaneous basement membrane components. Korean Journal of Investigative Dermatology, 14: 87-98, 2007. 
Yoo JM, Kang YJ, Pyo HB, Choung ES, Park SY, Choi JH, Han GJ, Lee $\mathrm{CH}$, Kim TJ. Anti-wrinkle effects of Korean rice wine cake on human fibroblast. Journal of Life Science, 20: 1838-1843, 2010. 


\section{국문초록}

\section{나이아신 펩타이드 융합체의 항주름 및 피부 턴오버 개선 효과}

김가연 ${ }^{1}$, 이승제 ${ }^{1}$, 전미지 $^{1}$, 김보민 ${ }^{1}$, 김근태 ${ }^{1}$, 강상문 ${ }^{2}$, 이기영 ${ }^{2}$, 신은진 ${ }^{2}$, 김상용 $^{3}$, 김영민 ${ }^{1 *}$

${ }^{1}$ 한남대학교 생명시스템과학과, 대전, 한국

${ }^{2}$ 에이앤펩 부설연구소, 충청북도 청주시, 한국

${ }^{3}$ 신안산대학교 식품생명과학과, 경기도 안산시, 한국

목적: 본 연구에서는 나이아신 펩타이드 융합체의 항주름 및 피부 턴오버 개선 효과를 입증하고 기능성 화장품 소재로서 이용 가능 성을 검증하고자 하였다. 방법: 3-(4,5-Dimethylthiazol-2-yl)-2,5-diphenyltetrazolium bromide (MTT) assay, wound healing assay, chicken choriallantoic membrane (CAM) assay, reverse transcription polymerase chain reaction (RT-PCR), 3D cell culture를 이용하여 나이아신 펩타이드 융합체의 항주름 및 피부 턴오버 개선 효과를 측정하였다. 결과: 나이아신 펩타이드 융합체 는 $\mathrm{HaCaT}$ 세포에 대해 독성이 없었고, 세포 이동 능력 회복 효과가 있으며, 이로 인해 피부 재생에 도움을 줄 수 있음을 확인하였 다. 또한 나이아신 펩타이드 융합체의 혈관 신생 효능을 확인한 결과, 양성 대조군 vitamin C와 유사한 것으로 확인되었다. 주름 표 지 인자인 $M M P-1,-2,-3,-9$ 의 발현양에 미치는 효과를 측정한 결과, MMPs 발현이 감소함을 확인하였다. 피부 에너지 대사 와 관련하여 Western blotting을 실시한 결과, 나이아신 펩타이드 융합체에 의해 피부 에너지 대사 활성이 증가함을 확인하였다. 마 지막으로 피부 턴오버 개선 효과를 확인한 결과, 양성대조군인 vitamin $\mathrm{C}$ 와 유사하거나 우수한 피부 턴오버 개선 효능이 있음을 확 인하였다. 결론: 본 연구 결과를 통하여 나이아신 펩타이드 융합체의 항주름 및 피부 턴오버 개선 효능을 확인하였으며, 기능성 화 장품 소재로서 이용 가능성이 높을 것으로 사료된다.

핵심어: 나이아신 펩타이드 융합체, 기능성 화장품, 항주름, 피부 장벽, 피부 턴오버

본 연구는 2016년도 중기청 융복합사업(과제번호: S2356755)에 의해 수행되었음.

\section{참고문헌}

고주영, 최경화, 김영철. 기니아 피그 동물모델에서 삼릉 에탄올추출물의 미백 효과. 환경독성보건학회지, 24: 219-229, 2009.

김도윤, 황대일, 윤미소, 최인호, 이환명. 산국화(Chrysanthemum boreale Makino) 유래 Hydrosol의 피부 각질형성세 포 증식 및 이주 유도 활성에 미치는 효과. 대한화장품학회지, 42: 95-101, 2016.

김석천, 홍남표, 추재학, 박수홍, 홍석찬, 차창일. 진주종 각질형성세포와 섬유아세포의 삼차원적 분리 공배양. 대한이비 인후과학회지 두경부외과학, $43: 1273-1278,2000$.

김영철, 박은예, 김상남, 유용기, 박미순, 이귀영, 이석준, 장병수. 홍차추출물 함유 누드팩의 Hairless 마우스 피부주름 형

성 억제효과. 한국현미경학회지, 41: 129-137, 2011.

김은아. 식물생리활성영양소와 미용기능식품. 식품과학과 산업, 40: 3-9, 2007.

김인덕, 권륜희, 허예영, 정혜진, 강환열, 하배진. 한방원료의 초임계 추출을 이용한 항노화 및 주름개선 효과. 한국생물공 학회지, 23: 529-534, 2008.

김정기, 이지해, 양미숙, 서대방, 이상준. 콜라겐 펩타이드의 피부 광노화 예방 효과. 한국식품과학회지, $41: 441-445$, 2009.

민정아, 배현숙. 천년초 손바닥 선인장 추출물을 적용한 MTS관리가 여성피부 개선에 미치는 영향. 아시안뷰티화장품학술

지, 11: 149-157, 2013. 
소승호, 이성계, 황의일, 구본석, 한경호, 정진호, 이민정, 김나미. 홍삼 생약 복합물(KTNG0345)의 피부 주름개선에 관한 작용기전. 고려인삼학회지, 32: 39-47, 2008.

손의동, 황재성, 장이섭. 항노화 화장품 연구 개발 동향. 대한화장품학회지, 31: 213-218, 2005.

송지성, 김영아. 국내 기능성 화장품 산업의 향후 시장 전망에 관한 연구: 코스메슈디컬 제품을 중심으로. 한국디자인문화 학회지, 15: 258-271, 2009.

양웅석, 김용민, 김이화, 서영배, 양윤정, 김현우, 강세찬. 사매추출물을 함유하는 화장품의 주름 개선 효과. 대한화장품학 회지, 36: 281-288, 2010.

유정민, 강여진, 표형배, 정의수, 박신영, 최지호, 한귀정, 이충환, 김택중. 양조 부산물인 주박의 주름개선 효과. 생명과학 회지, 20: 1838-1843, 2010.

윤호준, 신정원, 김연경, 김지은, 조광현. 피부의 기저막 구성성분의 발현에 미치는 비타민 $\mathrm{C}$ 와 비타민 $\mathrm{E}$ 의 효과. 대한피 부연구학회지, 14: 87-98, 2007.

이병근, 김종협, 함상경, 이창언. 화장품 개발을 위한 배롱나무(Lagerstroemia indica Linnaeus)가지 추출물의 생리활성 에 관한 연구. 한국자원식물학회지, 27: 29-34, 2014b.

이수연, 이진영. 섬유아세포(CCD-986sk)에서 청미래덩굴의 pro-collagen type-1 활성 및 MMP-1의 유전자 발현 저해 능. 생명과학회지, 23: 1239-1245, 2013.

전민희, 박미라, 박용수, 황현정, 김성구, 이상현, 김미향. 적송잎 추출물이 항산화 활성 및 파골세포의 증식에 미치는 영 향. 한국식품영양과학회지, 40: 525-530, 2011.

전영선, 강상모. 콜라겐 섭취가 안면피부 주름에 미치는 영향. 아시안뷰티화장품학술지, 7: 79-93, 2009.

정명근, 황영선, 김기쁨, 안경근, 심훈섭, 홍승범, 최재후, 유창연, 정일민, 김승현, 임정대. 맥문동 종실 안토시아닌 분획 물의 멜라닌 생성 억제 및 미백 효과. 한국약용작물학회지, 21: 361-371, 2013.

정해수, 송미영, 김형식, 서효현, 이정훈, 이경록, 홍일, 모상현. 갈릭산 펩타이드 유도체를 이용한 주름개선 소재 개발. 한 국산학기술학회지, 16: 5452-5457, 2015. 


\section{中文摘要}

\section{烟酰胺二肽融合体的抗皱和皮肤周期改善效果}

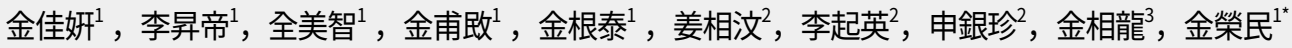

1韩南大学生命科学科, 大田, 韩国

${ }^{2} A \& P E P$ 附属研究所, 忠清北道清州市, 韩国

3新安山大学食品生命科学科, 京畿道安山市, 韩国

目的：探讨烟酰胺二肽融合体的抗皱以及皮肤周期改善效果, 确认作为功能性化妆品原料的应用可行性。方 法: 利用3-(4,5-dimethylthiazol-2-yl)-2,5-diphenyltetrazolium bromide (MTT) assay, wound healing assay, chicken choriallantoic membrane (CAM) assay, reverse transcription polymerase chain reaction (RT-PCR), 3D cell culture测定烟酰胺二肽融合体的抗波以及皮肤周期改善活性。结果：烟酰胺二肽融合体对 $\mathrm{HaCaT}$ 细胞不具有细胞毒性, 并具有恢复细胞迁移能力, 从而确认烟酰胺二肽融合体有助于皮肤再生。另外, 烟酰胺二肽融合体的的血管生成潜力被证实与阳性对照群维生素C相似。测定皱纹标记因子MMP-1, $-2,-3$ 和-9的表达水平结果显示, 降低了MMPs的表达水平。蛋白质印迹与皮肤能量代谢表明, 烟酰胺二肽融合体增 加了皮肤能量代谢活性。最后, 确认皮肤周期改善效果与阳性对照组维生素C相似, 或者皮肤周期改善效果优 异。结论: 通过以上研究, 确认烟酰胺二肽融合体的抗坡和皮肤周期改善效果, 并认为其作为功能性化妆品原 料充分具有利用可行性。

关键词：烟酰胺二肽融合体, 功能性化妆品, 抗波, 皮肤屏障, 皮肤周期改善 